\title{
A NOTE ON DIPLOGLOTTIS AUSTRALIS (G. DON) RADLK.
}

G. J. HARden \& L. A. S. JoHnSON

(Accepted for publication 3.4.1985)

\begin{abstract}
G. J. Harden \& L. A. S. Johnson (National Herbarium of New South Wales, Royal Botanic Gardens, Sydney, Australia 2000) 1986. A note on Diploglottis australis (G. Don) Radlk. Telopea 2(6): 745-748 - The application of the name Diploglottis australis (G. Don) Radlk. for the 'Native Tamarind' is supported and clarified. A lectotype for Cupania cunninghamii Hook. and a neotype for Stadmannia australis G. Don are designated.
\end{abstract}

Reynolds (1981) uses the name Diploglottis cunninghamii (Hook.) Hook. f. for the well known 'Native Tamarind' of southern Queensland and New South Wales rainforests. She rejects the name $D$. australis, citing it as published by Radlkofer in 1879 , and erroneously states that 'In making the combination Diploglottis australis Radlkofer cited it as D. australis (Cunn.) Radlk. and cited Stadmannia australis Cunn. as a synonym'. Apparently following Radlkofer's later treatment on the Sapindaceae (Radlkofer 1933) she says 'Radlkofer intended to base his name on $S$. australis Cunn. In his references to $S$. australis he also cited G. Don, Gen. Syst. 1 (1831) 669. Cunningham's name was published as a synonym without description whereas Don's was validly published and consequently Radlkofer's name has often been cited as $D$. australis (G. Don) Radlk.'. According to Reynolds 'the protologue of Stadtmannia [sic] australis G. Don does not apply to the plant described as Cupania cunninghamii (to which Hooker referred S. australis Cunn.) and by Radlkofer as Diploglottis australis', but she gives no evidence for this conclusion. Possibly she was following Domin (1927, p. 906) who, as a synonym under Diploglottis cunninghamii, cited 'Stadmannia australis A. Cunn. ex Hook. in Bot. Mag. LXXV sub t. 4470 (1849), non G. Don', but also gave no evidence for the exclusion of Don's plant.

Reynolds also claims that $D$. australis Radlk. 'should be regarded as a new name, not as a new combination, as it was based on an illegitimate name'. In fact, if Radlkofer's name had really been based on S. australis A. Cunn. it would have been based on an invalid name but, as we shall see, the basionym is in fact not $S$. australis A. Cunn. but S. australis G. Don.

The genus Diploglottis was established by J. D. Hooker (1862), who listed its single species as Australian, making no combination under Diploglottis but giving Cupania cunninghamii Hook. in Bot. Mag. 75, t. 4470 (1849) as a synonym. The combination $D$. cunninghamii (Hook.) Hook. f. ex Benth. was later made by Bentham (1863) who attributed it to the younger Hooker in Genera Plantarum (Hooker 1862), where, as stated above, it was implied but not formally made.

For the next hundred years, with the exception of Radlkofer, botanists ignored the earlier valid publication by G. Don in 1831 of Stadmannia australis. According to W. J. Hooker (1849) Stadtmannia [sic] australis was a 
manuscript name of Cunningham's, and the tree at Kew used by Hooker for his description of Cupania cunninghamii was labelled Stadtmannia australis. This plant, a native of New Holland, was stated to have been introduced into the 'Royal Gardens' (Kew) in 1825 but it did not flower till 1849.

In drawing up his description of the vegetative features of Stadmannia australis in 1831, Don indicated that it was introduced into greenhouse cultivation in Britain in 1820, and that it was a tree growing to 60 feet. He also noted that it could be grown from cuttings but did not indicate whether this particular plant was propagated from seed or cuttings. Don also stated that the trees had 'very shewy, large, pinnate leaves' and the 'young leaves and branches were covered with rusty down'. In his protologue he said 'leaves alternate, with 2 or 3 pairs of large, oblong, retuse, rather coriaceous, opposite leaflets, with an odd one'. This description of the leaves led Reynolds to reject Don's name on the grounds of doubt that the protologue could apply to the plant later described as Cupania cunninghamii. These doubts are unjustified. Generally, the seedlings of this species have large simple leaves, and saplings up to $2 \mathrm{~m}$ or more in height have leaves with 3,5 or 7 leaflets. However, in a number of instances specimens of leaves with 3 to 7 leaflets are at NSW with notes by the collectors as leaves from 'large tree', 'small tree' or 'saplings'. It is also recorded that sucker shoots have this number of leaflets. A specimen collected by Leichhardt (1843) consists of a fruiting branch accompanied by a large simple leaf and a leaf with 5 leaflets and the note 'leaf of a tree'.

It should be noted that Don and Hooker were basing their descriptions on different individual trees, but no specimens of either have been found.

The combination Diploglottis australis (G. Don) Radlk. was made not in 1879 but in an earlier publication (Radlkofer 1878, p. 278), where he referred Cupania cunninghamii Hook. and Stadmannia australis G. Don to this name. In his subsequent publication (1879) Radlkofer listed D. australis on p. 531 (as his numbered entry 372 ), giving references to his entries ' 80 (558), 652 (74, 373, 496)'. Several of these entries simply refer to synonyms of $D$. australis and under entry 496 Radlkofer synonymized the nomen nudum Melicocca australis Steud., apparently without any doubt as to its identity. Steudel in 1841 had referred 'Stadmannia australis R. Br.' to Melicocca without comment, Robert Brown having collected the plant in 1804 without formally describing it. There is no evidence of Brown giving this manuscript name but rather, as stated above, Hooker ascribed that name to Cunningham in manuscript. Even if it were not accepted that Radlkofer definitely established the combination $D$. australis (G. Don) Radlk. in 1878 there can be no doubt he established it in 1879. The critical entry in Radlkofer (1879) is No. 652 (p. 545), under which Radlkofer refers Stadmannia australis G. Don to 'Diploglottis australis Radlk.!'.

From the description, and taking into account W. J. Hooker's reference to 'Stadtmannia australis All. Cunn.' in the context of the general common knowledge of exchange of information among British botanists at the time, there is no reason to doubt that the protologue of Stadmannia australis G. Don applies to the species described by Hooker as Cupania cunninghamii and by Radlkofer as Diploglottis australis.

Stadmannia australis G. Don is not misapplied, but is conspecific with Cupania cunninghamii Hook. No author has suggested any other species to which Don's name might apply, and the protologue applies very well to this conspicious and well known species, which grows in areas north and south of 
Sydney visited by Brown, Cunningham and other early botanists and collectors. Hooker's protologue made use of a cultivated specimen as well as specimens collected in Australia by Cunningham and by Backhouse, together with Cunningham's notes. We see it as the most reasonable hypothesis that, in his general treatment of cultivated plants of that time, Don was in fact publishing, for this plant, the name that was already in common usage, at least in part because of the label on the plant at Kew 'Stadtmannia australis of Allan Cunningham'. The alternative to this implies that Don's plant belonged to some other species, despite the lack of any known candidate for such an identity. The 'Native Tamarind' is distinctive in its vegetative characters and Don's protologue fits it - the protologue does not imply that the leaves described came from the crown of a tree 60 feet in height. Thus we conclude that the overwhelming likelihood (which is all that scientific hypotheses are generally based upon) is that the correct name for the Australian 'Native Tamarind' should be Diploglottis australis (G. Don) Radlk. A name, in this case commonly used in New South Wales at least for three decades, should not be rejected on the basis of unsupported assertions that its basionym applies to something else (unspecified).

A specimen collected by Allan Cunningham* is nominated here as Neotype for Stadmannia australis G. Don and hence for Diploglottis australis (G. Don) Radlk. since inquiries at Edinburgh and Kew have revealed no specimen that might be a type of Stadmannia australis G. Don. It is from the general region where the plant that was introduced into cultivation in Britain was probably collected in the early 19 th century. This specimen is nominated also as Lectotype for Cupania cunninghamii Hook. and hence for Diploglottis cunninghamii (Hook.) Hook. f. ex Benth.

\section{ACKNOWLEDGMENTS}

We thank Dr Surrey Jacobs for examining specimens and forwarding information during his period as Australian Botanical Liaison Officer at the Royal Botanic Gardens, Kew, and the Regius Keeper at the Royal Botanic Gardens, Edinburgh, for the loan of a specimen. We are grateful to colleagues at the National Herbarium of New South Wales, especially Mrs Joy Thompson and Mrs Karen Wilson, for helpful discussions. Dr Hansjörg Eichler kindly checked the precise significance of part of Radlkofer's German text.

\section{CHRONOLOGY}

1804 Collected by R. Brown

(specimen at NSW, E \& BM)

1818 Stadtmannia australis A. Cunn. ms.

1820 Cultivated in Britain

1825 Introduced to Kew

(labelled 'Stadtmannia australis of Allan Cunningham', flowered in 1849)

\section{Stadmannia australis G. Don}

(cultivated 1820 , non-flowering as at 1831)

\footnotetext{
*Neotype: 'on the banks of the Hastings River, at Port Macquarie', Allan Cunningham n. 14, s. d. (K, n. v.; examined by Dr Surrey Jacobs on our behalf).
} 
1841 Melicocca australis Steud. nomen nudum

(based on R. Br. collection)

1849 Cupania cunninghamii Hook.

1862 Diploglottis Hook. f. (based on tree in flower at Kew, specimens collected in Australia, and Cunningham's notes)

(based on Cupania cunninghamii but no combination made)

1863 Diploglottis cunninghamii (Hook.) Hook. f. ex Benth.

in Flora Australiensis

1878 Diploglottis australis (G. Don) Radlk.

\section{REFERENCES}

Bentham, G. (1863). 'Flora Australiensis' (Lovell Reeve \& Co: London) vol. 1, p. 454 .

Domin, K. (1927). Beiträge zur Flora und Pflanzen-geographie Australiens. Biblioth. Bot. 22(89): 905.

Don, G. (1831). 'A General History of the Dichlamydeous Plants' (Gilbert \& Rivington: London) vol. 1, p. 669.

Hooker, J. D. (1862). Sapindaceae. In Bentham, G. \& Hooker, J. D., 'Genera Plantarum' (Lovell Reeve \& Co: London) vol. 1, p. 395.

Hooker, W. J. (1849). Cupania cunninghami. Bot. Mag. 75, t. 4470.

Radlkofer, L. (1878). Über Sapindus und damit in Zusammenhang stehende Pflanzen. Sitzungsber. Bayer. Akad. Wiss. 8: 278.

Radlkofer, L. (1879). Uber Cupania und damit verwandte Pflanzen. Sitzungsber. Bayer. Akad. Wiss. 9: 486, 499, 513, 514, 531, 536, 539, 545.

Radlkofer, L. (1933). Sapindaceae. In Engler, A. \& Diels, L., 'Das Pflanzenreich' iv. 165 (Engelmann: Berlin), pp.1224-6.

Reynolds, S. (1981). Notes on Sapindaceae in Australia, I. Austrobaileya 1(4): 396-7.

Steudel, E. G..(1841). 'Nomenclator Botanicus' (Tubingen, Stuttgart) edn 2; vol. 2, p. 120 .

Manuscript submitted 11.4.1984. 